\title{
The aesthetics of anti-social behaviour
}

Andrew Millie

\section{PRE-PUBLICATION VERSION}

Published as:

Millie, A. (2014) 'The aesthetics of anti-social behaviour', in S. Pickard (ed.) Anti-Social Behaviour in Britain: Victorian and Contemporary Perspectives, Basingstoke: Palgrave Macmillan.

\begin{abstract}
From the late-1990s onwards, anti-social behaviour has been high on the political agenda in Britain. This chapter draws on philosophical, criminological and other writings to unpick some influences of aesthetic taste on what is perceived to be anti-social. The meaning and subjectivity of aesthetic judgment are considered, with examples given that may lead to censure and 'banishment' - such as wearing a hoodie, writing the wrong sort of graffiti or being visibly homeless. Due to its influence on British policy, Wilson and Kelling's (1982) 'broken windows' is given particular attention and, in line with Ferrell (2006), is seen as an aesthetic theory that makes various assumptions as to what - or who - act as signals of urban decay. The chapter considers whether it is ever right to censure aesthetic taste and simply banish the unsightly. Instead, it is suggested that respect for difference could alternatively be promoted.
\end{abstract}

Key words: aesthetics; anti-social behaviour; broken windows; taste; value judgments

\section{Introduction}

From the late-1990s onwards, anti-social behaviour has been high on the political agenda in Britain. Of course, at the end of the twentieth century, anti-social behaviour was nothing new, a fact highlighted in other contributions to this volume. Yet, following pressure on MPs from constituents facing difficulties with people labelled as 'neighbours from hell' (Straw, 1996; Field, 2003) - and influenced by American zero-tolerance policing strategies (Millie, 2009a) - the 1997-2010 New Labour government made anti-social behaviour one of its key policy targets. Being anti-social was defined by New Labour as behaving 'in a manner that caused or was likely to cause harassment, alarm or distress to one or more persons not of the same household as [the perpetrator]' (Crime and Disorder Act, 1998, s.1(1a)). As has been well documented (Ashworth et al., 1998; Ramsay, 2004; Millie, 2009a), there were issues with such a vague definition. In the first instance, what causes me harassment, alarm or distress may be quite different for someone else. Deciding what or who 'was likely' to be anti-social was even more subjective and problematic.

This chapter considers such subjective interpretations. Specifically, the focus is on aesthetic determinants of perceived anti-social behaviour - whilst acknowledging that there are clearly other influences on perception (see e.g. Jacobson, Millie and Hough, 2008; 
Mackenzie et al., 2010). The discussion draws on philosophical, criminological and other writings to unpick some influences of aesthetic taste on what is perceived to be anti-social. For instance, the chapter considers aesthetic interpretations of dress (such as the hoodie) that may lead police officers to see someone as potentially anti-social. Furthermore, proponents of a particular style of graffiti may be censured, yet others may fit an agreeable aesthetic and be celebrated. As for talk of 'neighbours from hell,' problems may stem from serious behavioural issues, but may also concern conflicting tastes. However, is it right to censure taste, something that is both subjective and emotive? This chapter considers the impact of aesthetic taste on others and how differences in lifestyle can lead to some being labelled as anti-social.

Like New Labour before it, the 2010 Conservative-Liberal Democrat Coalition government identified anti-social behaviour as an important policy issue (Millie, 2013). According to the Conservative Home Secretary Theresa May (2012: 3), 'No one should have to accept graffiti on their walls, public drunkenness on their streets or harassment and intimidation on their own doorstep.' At first, it is hard to argue with such logic, that everyone wants somewhere 'nice' to live. Yet each part of this statement is subjective. Harassment and intimidation are perhaps less problematic, as very few people would want to put up with these types of behaviours - although tolerances may vary. Public drunkenness is again something that at first seems uncontroversial. Yet there is an aesthetic to public drunkenness which means some drunks are more acceptable than others. For example, city workers drinking outside a pub at $5 \mathrm{pm}$ on a Friday are usually an accepted part of city life; yet a street homeless person drinking at lunchtime may be less acceptable. As for May's statement that 'No one should have to accept graffiti on their walls,' this becomes problematic when certain forms of graffiti and street art can act as attractors for tourists and part of what makes an urban district 'edgy' - and therefore an attractive place to live. Here graffiti contributes to processes of gentrification rather than decline as often assumed (Young, 2014).

In this chapter, the meaning and subjectivity of aesthetic judgment are considered. The relevance of aesthetics to assessments of anti-social behaviour is then explored and examples are given of aesthetic judgments leading to censure and 'banishment.' James Wilson and George Kelling's (1982) 'broken windows' perspective has been especially influential to British anti-social behaviour policy. Because of this influence, broken windows is given particular attention. In line with Jeff Ferrell (2006), this is seen as an aesthetic theory that makes various assumptions as to what - or who - act as signals of urban decay. The chapter finishes by discussing whether it is ever right to censure aesthetic taste, before concluding that it can be a mistake to enforce subjective taste and simply banish the unsightly. Instead, it is suggested that respect for difference could alternatively be promoted. However, first it is worth unpacking what is meant by aesthetic judgment.

\section{Aesthetic judgment}

Aesthetics has for many years been a concern of philosophy and art criticism focusing mainly on questions pertaining to what makes art good and whether there is such a thing as objective beauty. William Gilpin (1786), for example, considered criteria that made a landscape beautiful or sublime. Writing around the same time Immanuel Kant concluded that beauty is subjective, that 'an objective principle of taste is impossible' (1790/2011: 12). In effect, according to Kant, there can be no objectively beautiful or sublime landscape (or 
objectively beautiful or sublime anything else), only our interpretations depending on taste. Thus, building on a Kantian perspective, I take the view that aesthetics is concerned with taste, with subjective and emotive values attached to sensory encounters (Millie, 2008; 2011). For an example, Kant considered the beauty of a flower:

To say, This flower is beautiful, is tantamount to a mere repetition of the flower's own claim to everyone's liking. The agreeableness of its smell, on the one hand, gives it no claim whatsoever: its smell delights one person, it makes another dizzy [...] beauty is not a property of the flower itself. For a judgment of taste consists precisely in this, that it calls a thing beautiful only by virtue of the characteristics in which it adapts itself to the way we apprehend it (Kant, 1790/2011: 10).

This subjectivity of aesthetic taste has direct relevance to the acceptability - or otherwise of certain anti-social behaviours. Following Kant, there can be no agreed list of graffiti or street art styles that are always aesthetically acceptable. Groups of young people wearing hoodies may be turned away from one location because they do not adhere to a particular aesthetic being promoted, yet accepted elsewhere. A visibly homeless person may be moved on from a high end retail district, but ignored in another.

For some, aesthetic preferences are restricted to visual and aural stimuli. For Kant's flower, there was also the influence of smell. You can add to this all other senses and beyond. This chapter is concerned with what Yuriko Saito (2007) refers to as everyday aesthetics. Influenced by Henri Lefebvre's (1961/2008) 'everyday life,' everyday aesthetics relates to everyday objects, events and encounters. For instance, reading a message left by a graffiti writer is an everyday aesthetic experience, and so too is feeling the texture of a 'guerrilla knitter's' crocheted wool that has been left without permission enveloping a tree (see Deadly Knitshade, 2011). Encountering the graffiti and guerrilla knitting may be negative aesthetic experiences - and perceived as anti-social by some - yet for others they may add something positive to the urban experience that make the city somewhere that is more pleasurable to be.

Inherent to aesthetic judgments are ideas of taste, and relatedly notions of good taste and bad taste. In relation to graffiti, Germaine Greer once commented, 'Instead of spending a fortune getting rid of it, why don't we just give it marks out of 10?' (Greer, 2007; Millie, 2008). Presumably, those doing the scoring will have 'good taste'? Greer may have been deliberately provocative with such a statement, yet, as this chapter will demonstrate, the statement gets to the heart of the problem of mixing aesthetic judgment with assessments of what is acceptable or anti-social. A graffiti writer that scores low on Greer's scale will no doubt face prosecution, whereas a high scorer - Banksy perhaps? - will be celebrated. In relation to questions of taste and neighbourliness, according to the conservative philosopher Roger Scruton (2009: 133-4):

In a democratic culture people are inclined to believe that it is presumptuous to claim to have better taste than your neighbour. By doing so you are implicitly denying his right to be the thing that he is. You like Bach, she likes U2 [...] she likes Jane Austen, you like Danielle Steel. Each of you exists in his own enclosed aesthetic world, and so long as neither harms the other, and each says good morning over the fence, there is nothing further to be said. [...] [But] your neighbour fills her garden with kitsch mermaids and Disneyland gnomes, polluting the view from your window. [...] Now her taste has ceased to be a private matter and inflicted itself on the public realm. 
It is when someone's private taste becomes public that it may be interpreted as anti-social be that someone's taste in graffiti or gnomes and mermaids. In the above example, having a garden full of gnomes and mermaids may be perceived as anti-social, in the same way that growing a high hedge could be anti-social, because it is inconsiderate of neighbours. According to the Anti-Social Behaviour Act 2003 (s.66), a high hedge is defined as causing:

so much of a barrier to light or access as (a) is formed wholly or predominantly by a line of two or more evergreens; and (b) rises to a height of more than two metres above ground level.

A private taste - a liking for tall hedges and privacy - has become public by restricting the amount of sunlight reaching a neighbour or making access to a neighbour's property more difficult. Much criminological and legal theory emphasize harm and offence as determinates of criminalization (Feinberg, 1984; 1985; Hillyard et al., 2004; von Hirsch and Simester, 2006). With the example of 'high hedges,' it is the practical harm to quality of life that is important; but also the aesthetic offence and maybe moral offence that a neighbour would inflict their taste on you, a taste for high hedges that you do not share. This is similarly the case for the garden gnomes and mermaids; however there may also be economic impacts by lowering the attractiveness of the street and thereby deflating property prices.

According to Carolyn Korsmeyer (2005: 275), 'Those who conceive of themselves as having good taste may condescend to those with "inferior" tastes, while the later may consider the former mere snobs [...].' It is questionable why one person's taste should take precedence over another's - even if the other's taste is for gnomes and mermaids. This was a point picked up by Pierre Bourdieu (1979/2010) in charting an aristocracy of culture from popular taste, through middle-brow to the 'legitimate' tastes of the ruling classes. There are clearly issues of power in who defines what is acceptable, or what Ferrell (1996) has termed an aesthetics of authority. Those deemed to have poor aesthetic taste tend to be the powerless. When censured as anti-social the consequences of such assessments become more serious.

\section{Aesthetics and banishing the anti-social}

The mixing of aesthetic judgment and censure has historic precedent, especially in relation to the fashion of offenders (and those thought likely to offend). In the eighteenth century, the Black Act 1723 meant having your face blackened or being otherwise disguised was a capital offence (Treadwell, 2008). Determining what constitutes a disguise may not have been straightforward. In Victorian Britain, dressing in a fashion similar to a 'Hooligan', 'Peaky Blinder' or 'Scuttler' could have landed you in all sorts of trouble (Pearson, 2009). Similar stereotypes persist today making some young people more likely to attract the attention of the police than others, as those likely to be anti-social and in need of dispersal. The hoodie, along with a baseball cap, 'designer' sports attire and trainers is the uniform of the 'chav'1 (Hayward and Yar, 2006) or 'ned'2 (Brown, 2008) - the young working class that, to use Korsmeyer's words (2005: 275), are condescended as having 'inferior tastes.' Famously, the Bluewater shopping centre in Kent was the first to ban the wearing of hoodies (Hayward and Yar, 2006; Millie, 2009a), ostensively so that all could be seen by their CCTV systems; but also to ally the prejudicial concerns of other customers that hoodie 
wearing youths were anti-social - despite hoodies being on sale within the shopping centre. According to Hayward and Yar:

[...] street-level attempts to mobilize cultural capital based on overt displays of designer clothing have instead inspired a whole new raft of bizarre micro social control mechanisms, including everything from town centre pubs and night clubs refusing entry to individuals wearing certain brands within their premises [...] to the recent 'zero tolerance' policy imposed on 'designer hoodies' and baseball caps [...] by major shopping centres [...]. Thus the situation arises in which many of the labels and monograms valorized by young people as badges of identity serve also to function as overt signifiers of deviance. As such they become tools of classification and identification by which agencies of social control construct profiles of potential criminal protagonists (2006: 22-3).

Not only are the young stereotypically regarded as 'problem' populations, but so too the poor. To be young and poor amplifies the potential threat. Aesthetics is relevant to both groups as aesthetic cues - including dress codes - can influence initial assessments of what type of person someone is (although, of course, such assessments are not always accurate). Charles Baudelaire's poem 'The eyes of the poor' encapsulates the ruling class's aesthetic assessment of the poor. In the poem, two lovers enjoy a new café in George Haussmann's redesigned nineteenth century Paris. As retold by Marshall Berman (1982: 149):

As the lovers sit gazing happily into each other's eyes, suddenly they are confronted with other people's eyes. A poor family dressed in rags - a graybearded father, a young son, and a baby - come to stop directly in front of them and gaze raptly at the bright new world that is just inside [...]. He is 'touched by this family of eyes' [...]. 'I turned my eyes to look into yours dear love, to read my thoughts there' [...] she says, 'These people with their great saucer eyes are unbearable! Can't you tell the manager to get them away from here?' (Berman, 1982: 149).

The visible presence of the poor does not meet the lover's aesthetic expectations. The sight of 'a poor family dressed in rags' jars with the romance of the situation. What the lover calls for is what, in a North American context, Katherine Beckett and Steve Herbert (2010) have called banishment. In Seattle, for example:

Increasing swathes of urban space are delimitated as zones of exclusion from which the undesirable are banned. The uniformed police are marshaled to enforce and often delineate these boundaries; they use their powers to monitor and arrest in an attempt to clear the streets of those considered unsightly or 'disorderly' (Beckett and Herbert, 2010: 8).

Key here is the idea of banishing the 'unsightly.' As Beckett and Herbert emphasize, the situation is not unique to Seattle. It is also a common approach in Britain, for instance with the use of Dispersal Orders ${ }^{3}$ to move on those thought likely to be anti-social (Crawford and Lister, 2007). As already mentioned, street drinking city workers are more acceptable than a street drinking homeless person, with the homeless person regarded as 'unsightly' and moved on. Furthermore, the homeless person's contribution to the local economy is not on the scale of the city workers' - and if you are not making a significant contribution to the economy your presence is more likely to be criminalized (Coleman, 2004; Millie, 2011). Such aesthetic - and economic - assessments can be seen as part of revanchist processes of revitalization and gentrification (Smith, 1996). Alongside aesthetic and economic value judgments are moral and prudential/quality-of-life assessments (Millie, 2011). For instance, for the homeless person, is it morally right to be living on the street? Or perhaps, are the 
viewers' morals challenged and quality-of-life affected by the sight of such visible poverty leading to calls to 'get them away from here'? (cf. Berman, 1982). All four value judgments inter-relate in determining what or who are acceptable or deemed to be anti-social and banished. An influential American perspective that incorporates these value judgments is Wilson and Kelling's (1982) 'broken windows.' Their view has had a major influence on British anti-social behaviour policy and it is to this that I now turn.

\section{The aesthetics of breaking windows}

A lot has been claimed about 'broken windows,' both for and against; as Kelling (2000: 12) later observed, 'it has caused considerable consternation in much sociological, legal and criminological literature.' Kelling was right in that the 'broken windows' perspective has been critiqued at length (e.g. Walker, 1984; Sampson and Raudenbush, 1999; Harcourt, 2001; Mitchell, 2001), as has the zero tolerance policing that it inspired in New York and Britain from the 1990s onwards (e.g. Bowling, 1999; Smith, 2001). It is not my job here to repeat all has been said before. What 'broken windows' provides is a simplified story causally linking disorder (or anti-social behaviour) to crime. The broken window is read as a signal of neglect, leading 'good' citizens to withdraw from the streets resulting in less informal control, more broken windows and for crime to take root. It is the job of the police and other agents of social control to get in early before such decline can take root. Despite the prominence of 'broken windows,' Wilson and Kelling were not the first to express such a view, although they were perhaps the first to link it to policing strategies. In the American states of California and New York, Philip Zimbardo (1973) had already run an experiment with abandoned cars to see how long it would be before they were vandalized and stripped for parts. In Britain, Colin Ward (1973) had also considered relationships between the environment and vandalism, according to whom:

An atmosphere of dereliction and neglect evokes misuse and careless, if not wilful, destruction, by some users, while good maintenance and surfaces of good quality, are respected and sometimes cherished. The environment, in other words, transmits signals to which users respond. Following this theory, one architect who was conscious of the usual drab, cold, litter-strewn appearance of staircase landings in blocks of flats, persuaded his client that it was useful to carpet the landing and provide a radiator. Over the radiator he installed a shelf, and was later gratified to see that a tenant had put a bowl of flowers on the shelf. The signal read CIVILIZED (Ward, 1973: 14).

In this regard, aesthetic signals are read as either signs of civilization or de-civilization or somewhere in-between - of something that is celebrated, merely tolerated or censured as being anti-social or criminal. A carpeted hallway is usually going to be seen as more attractive than one strewn with litter and graffiti. However, as noted, our assessments of aesthetic worth are both subjective and emotive, thus some forms of graffiti may in fact be welcomed in particular circumstances - although perhaps not the litter.

According to Ferrell (2006: 261-2), "broken windows" is essentially an aesthetic analysis of crime's etiology.' In effect, our interpretations of aesthetic signals lead to assessments of what is criminal, anti-social, tolerable or celebrated. It is an attractively simple idea, yet problematic for those people read as broken windows - the street homeless person, the graffiti writer, the hoodie wearing youth - who are then banished from public view. As Wilson and Kelling suggest, 'Arresting a single drunk or a single vagrant who has harmed no identifiable person seems unjust, and in a sense it is. But failing to do 
anything about a score of drunks or a hundred vagrants may destroy an entire community' (1982: 35). For Wilson and Kelling the homeless person is a signal of decline that makes other crime more likely. For Don Mitchell (2001), the logic is incredible, that homeless people should be punished, not for any crimes they have done, but 'because of the potential in a particular place for other people's crimes to occur' (2001: 68). Mitchell further notes:

[T]his defence of punitive measures against homeless people simply asserts that the aesthetics of place outweigh other considerations, such as the right of homeless people to find a means to live, to sleep, to be (Mitchell, 2001: 68, emphasis in original).

The study of semiotics is useful in trying to interpret such aesthetic signals (e.g. Barthes, 1972; Eco, 1979) and the idea of signal crimes and signals of control was later elaborated by Martin Innes and colleagues (e.g. Innes and Fielding, 2002). Roland Barthes (1972), for example, followed a semiotic-structuralist approach where signs mean the same to all readers. An alternative perspective - adopted in this chapter - takes an interpretivist view 'where individuals are creative agents that make their own meanings' (Millie, 2012: 1094). Wilson and Kelling clearly adopted a structuralist approach assuming that we all make the same aesthetic judgments. As mentioned, there can be quite different interpretations of graffiti writing or street art, which can be censured in one situation, yet celebrated as part of urban life elsewhere. The act of breaking a window itself can have different interpretations. A year before Wilson and Kelling published 'broken windows,' the Irish rock band $\mathrm{U} 2$ released their second album that included the track 'I threw a brick through a window' (U2, 1981). For Bono, the writer of the lyric, the broken window was not read as a signal of neighbourhood disorder or decline and something to be feared; rather, breaking a window was expressive and a metaphor for youthful frustration; as he declared elsewhere in the song:

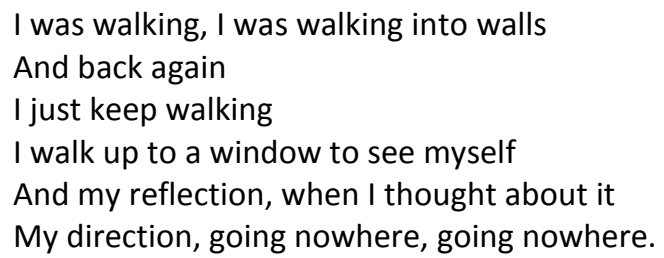

The broken window was important for what it signified to the one breaking the window, it was a positive thing. Similarly, for the street artist or graffiti writer, their uncommissioned images and words (cf. Young, 2014) are part of who they are, even if this is not read the same by all of their audience. As the British street artist Banksy once noted, perhaps with a hint of irony, 'Some people become cops because they want to make the world a better place. Some people become vandals because they want to make the world a better looking place' (Banksy, 2006: 8, emphasis in original). Urban developers and gentrifiers are attracted to such an 'edgy' aesthetic. In a critique of broken windows, Harcourt (2001: 18) declared that, 'the meaning of order and disorder may not be as stable or as fixed as the order maintenance approach suggests.' For Wilson and Kelling, however, broken windows were entirely negative aesthetic signifiers of disorder, crime and decline. 


\section{Conclusion}

What this chapter has attempted to demonstrate is that aesthetics have an important role in determining what is acceptable or anti-social and that such assessments have a disproportionate impact on the powerless. In line with Bourdieu (1979/2010), a hierarchy of tastes can be observed with more 'legitimate' tastes being reserved for those with power. The powerful may be shopping mall owners who exclude hoodie wearing youths for fear of upsetting the 'consuming majority' (cf. Bannister, Fyfe and Kearns, 2006). They may be gallery owners, collectors, celebrities or media outlets that tell us that certain street artists are worthy of attention, while others are guilty of vandalism. They may be police officers, urban planners or town centre managers who permit certain types of street drinking, yet are less tolerant of other street drinkers. As Korsmeyer (2005: 275) has noted, 'Those who conceive of themselves as having good taste may condescend to those with "inferior" tastes.' Utilising anti-social behaviour legislation, those with 'inferior taste' are deemed to be 'broken windows' to be dispersed or 'banished' (cf. Beckett and Herbert, 2010).

According to Scruton (2009: 134), 'Implicit in our sense of beauty is the thought of community - of the agreement in judgements that makes social life possible and worthwhile.' The example given is of planning law, yet would also apply to anti-social behaviour law. It is a majoritarian perspective where the views or tastes of the majority in society take precedence. Thus, having a garden full of mermaids and gnomes is a minority taste - and may be regarded as anti-social. However, I return here to a question I started with: is it right to censure taste, something that is both subjective and emotive? Furthermore, should one person's taste take precedence over another's, even if theirs is a minority perspective? There will always be some whose taste is so harmful or offensive that censure is the right response. For instance, it is sensible to have laws that censure graffiti that is racist/sexist/homophobic or displays other clearly insulting or inflammatory text, what - in the language of anti-social behaviour - would be true "harassment, alarm or distress.' Or perhaps law that limits who/when certain aesthetic tastes are permitted - such as having age limits on having a tattoo (e.g. BBC News, 2014). However, there is a lot below this level that is open for discussion as being simply 'different.'

Perhaps, instead of seeking agreement in aesthetic taste, we should seek respect for difference. In British policy on anti-social behaviour the word 'respect' comes with the baggage of New Labour's 'Respect agenda' (Millie, 2009b); yet it is an idea that can still have resonance. Rather than trying to enforce respect (as New Labour did through its anti-social behaviour legislation), the emphasis ought to be on promoting mutual understanding. According to Carla Bagnoli (2007: 117), 'respect requires that we do not impose our views on others, but it also requires that we engage in a frank dialogue with them [...] the conclusion of this dialogue may be informed disagreement.' If decisions concerning what is anti-social - and therefore censured - are informed by aesthetic taste, the idea of always imposing taste on others is not very attractive, especially if those deemed to have inferior tastes are those who already lack power. Instead, promoting the idea of 'informed disagreement' and at least some tolerance of difference (Bannister and Kearns, 2009) makes a lot of sense. Of course this does not diminish the serious impact in terms of harm or offence that some people's anti-social behaviour can have on others. However, it does leave hope for the promotion of empathy, or at least recognising the other's point of view. For Richard Sennett (1970: 108), this is the mature view of city living, to 'grow to need the unknown, to feel incomplete without a certain anarchy in their lives, to learn [...] to love the 
'otherness' around them.' However, as New Labour has demonstrated - and the Coalition has reinforced through the 2014 Anti-Social Behaviour, Crime and Policing Act - enforcing standards of behaviour continues to take precedence. However, as this chapter has attempted to demonstrate, it can be a mistake to simply enforce subjective taste and banish the unsightly.

\section{References}

Arrigo, Bruce A. and Williams, Christopher R. (eds.) (2006). Philosophy, Crime, and Criminology. Urbana and Chicago: University of Illinois Press.

Ashworth, Andrew., Gardner, John., Morgan, Rod., Smith, A.H.T., von Hirsch, Andrew. and Wasik, Martin. (1998). 'Neighbouring on the oppressive: The Government's 'AntiSocial Behaviour Order' proposals.' Criminal Justice, 16(1): 7-14.

Bagnoli, Carla. (2007). 'Respect and membership in the moral community.' Ethical Theory and Moral Practice, 10(2): 113-28.

Banksy. (2006). Wall and Piece. London: Century.

Bannister, Jon., Fyfe, Nick. and Kearns, Ade. (2006). 'Respectable or respectful? (In)civility and the city.' Urban Studies, 43(5/6): 919-37.

Bannister, Jon. and Kearns, Ade. (2009). 'Tolerance, respect and civility amid changing cities,' in Andrew Millie (ed.) Securing Respect: Behavioural Expectations and Antisocial Behaviour in the UK. Bristol: The Policy Press, 171-192.

Barthes, Roland. (1972). Mythologies. Translated by A. Lavers. New York: Hill and Wang.

BBC News. (2014). 'More under 18s are taking risks with illegal tattoos,' BBC News Online, 3 February, Available at: www.bbc.co.uk/news/uk-26013128 [Accessed 3 February 2014]

Beckett, Katherine. and Herbert, Steve. (2010). Banished: The New Social Control in Urban America. New York: Oxford University Press.

Berman, Marshall. (1982). All That is Solid Melts into Air: The Experience of Modernity. New York, NY: Penguin Books.

Bourdieu, Pierre. (1979/2010). Distinction: A Social Critique of the Judgement of Taste. London: Routledge.

Bowling, Benjamin. (1999). 'The rise and fall of New York murder: Zero tolerance or crack's decline?' British Journal of Criminology, 39(4): 531-54.

Brown, Alison. (2008). 'The war on 'Neds': Media reports as evidence base.' Criminal Justice Matters, 59, 16-7.

Cazeaux, Clive. (ed.). (2011). The Continental Aesthetics Reader. Second Edition, Abingdon: Routledge.

Coleman, Roy. (2004). Reclaiming the Streets: Surveillance, Social Control and the City. Cullompton: Willan.

Crawford, Adam. and Lister, Stuart. (2007). The Use and Impact of Dispersal Orders: Sticking Plasters and Wake-up Calls. Bristol: The Policy Press.

Deadly Knitshade. (2011). Knit the City: A Whodunnknit set in London. Chichester: Summersdale.

Dockley, Anita. and Loader, Ian. (eds.). (2013). The Penal Landscape: The Howard League Guide to Criminal Justice in England and Wales. London: Routledge.

Eco, Umberto. (1979). A Theory of Semiotics. Bloomington, IN: Indiana University Press. 
Feinberg, Joel. (1985). Offence to Others: The Moral Limits of the Criminal Law Volume 2. New York: Oxford University Press.

Feinberg, Joel. (1984). Harm to Others: The Moral Limits of the Criminal Law Volume 1. New York: Oxford University Press.

Ferrell, Jeff. (2006). 'The aesthetics of cultural criminology,' in Bruce A. Arrigo and Christopher R. Williams (eds.) Philosophy, Crime, and Criminology, Urbana and Chicago: University of Illinois Press, 257-78.

Ferrell, Jeff. (1996). Crimes of Style: Urban Graffiti and the Politics of Criminality. Boston: Northeastern University Press.

Field, Frank. (2003). Neighbours from Hell: The Politics of Behaviour. London: Politico's.

Gaut, Berys. and Mclver Lopes, Dominic. (eds.). (2005). The Routledge Companion to Aesthetics. $2^{\text {nd }}$ Edition, London: Routledge.

Gilpin, William. (1786). Observations, Relative Chiefly to Picturesque Beauty, Made in the Year 1772, On Several Parts of England; Particularly the Mountains and Lakes of Cumberland and Westmoreland, Vol. 1. London: R. Blamire.

Greer, Germain. (2007). 'What should we do about graffiti?: Instead of spending a fortune getting rid of it, why don't we just give it marks out of 10?' The Guardian, 24 September, Available

at: www.theguardian.com/artanddesign/artblog/2007/sep/24/whatshouldwedoaboutgra ffiti [Accessed 4 February 2014]

Harcourt, Bernard E. (2001). Illusion of Order: The False Promise of Broken Windows Policing. Cambridge MA: Harvard University Press.

Hayward, Keith. and Yar, Majid. (2006). 'The 'Chav' phenomenon: Consumption, media and the construction of a new underclass.' Crime, Media, Culture, 2(1): 9-28.

Hillyard, Paddy., Pantazis, Christina., Tombs, Steve. and Gordon, Dave. (eds.). (2004). Beyond Criminology: Taking Harm Seriously. London: Pluto Press.

Innes, Martin. and Fielding, Nigel. (2002). 'From community to communicative policing: "Signal crimes" and the problem of public reassurance.' Sociological Research Online, 7(2). Available at: www.socresonline.org.uk/7/2/innes.html [Accessed 5 February 2014]

Jacobson, Jessica., Millie, Andrew. and Hough, Mike. (2008). 'Why tackle anti-social behaviour?' in P. Squires (ed.) ASBO Nation: The Criminalisation of Nuisance. Bristol: The Policy Press, 37-56.

Kant, Immanuel. (1790/2011). 'Extracts from "Analytic of Aesthetic Judgment" and "Dialectic of Aesthetic Judgment", Critique of Judgment,' in Clive Cazeaux (ed.). The Continental Aesthetics Reader. Second Edition, Abingdon: Routledge, 3-39.

Kelling, George L. (2000). "Broken windows" and the culture wars: A response to selected critiques,' in Roger Matthews and John Pitts (eds.). Crime, Disorder and Community Safety: A New Agenda? London: Routledge, 120-44.

Korsmeyer, Carolyn. (2005). 'Taste,' in Berys Gaut and Dominic Mclver Lopes (eds.). The Routledge Companion to Aesthetics. $2^{\text {nd }}$ Edition, London: Routledge, 267-79.

Lefebvre, Henri. (1961/2008). Critique of Everyday Life, Introduction. Volume 1, translated by John Moore, London: Verso.

Mackenzie, Simon., Bannister, Jon., Flint, John., Parr, Sadie., Millie, Andrew. and Fleetwood, Jennifer. (2010). The Drivers of Perceptions of Anti-Social Behaviour. Home Office Research Report 34. London: Home Office. 
May, Theresa. (2012). 'Home Secretary Foreword', in Putting Victims First: More Effective Responses to Anti-Social Behaviour. Cm 8367. London: The Stationery Office.

Matthews, Roger. and Pitts, John. (eds.). (2001). Crime, Disorder and Community Safety: A New Agenda? London: Routledge.

Millie, Andrew. (2013). 'Replacing the ASBO: An opportunity to stem the flow into the Criminal Justice System,' in Anita Dockley and Ian Loader (ed.) The Penal Landscape: The Howard League Guide to Criminal Justice in England and Wales. London: Routledge, 64-88.

Millie, Andrew. (2012). 'Police stations, architecture and public reassurance.' British Journal of Criminology, 52(6): 1092-112.

Millie, Andrew. (2011). 'Value judgments and criminalization.' British Journal of Criminology, 51(2): 278-95.

Millie, Andrew. (2009a). Anti-Social Behaviour. Maidenhead: Open University Press.

Millie, Andrew. (2009b). Securing Respect: Behavioural Expectations and Anti-Social Behaviour in the UK. Bristol: The Policy Press.

Millie, Andrew. (2008). 'Anti-social behaviour, behavioural expectations and an urban aesthetic.' British Journal of Criminology, 48(3): 379-94.

Minca, Claudio. (ed.). (2001). Postmodern Geography: Theory and Praxis. Oxford: Blackwell.

Mitchell, Don. (2001). 'Postmodern geographical praxis? Postmodern impulse and the war against homeless people in the 'Post-Justice' city,' in Claudio Minca (ed.). (2001). Postmodern Geography: Theory and Praxis. Oxford: Blackwell, 57-92.

Pearson, Geoffrey. (2009). "A Jekyll in the classroom, a Hyde in the street": Queen Victoria's hooligans,' in Andrew Millie (ed.). Securing Respect: Behavioural Expectations and Anti-Social Behaviour in the UK. Bristol: The Policy Press, 41-71.

Ramsay, Peter. (2004). 'What is anti-social behaviour?' The Criminal Law Review, November, 908-25.

Saito, Yuriko. (2007). Everyday Aesthetics. Oxford: Oxford University Press.

Sampson, Robert J. and Raudenbush, Stephen W. (1999). 'Systematic social observation of public spaces: A new look at disorder in urban neighbourhoods.' American Journal of Sociology, 105(3): 603-51.

Scruton, Roger. (2009). Beauty. Oxford: Oxford University Press.

Sennett, Richard. (1970). The Uses of Disorder: Personal Identity and City Life. New York, NY: W.W. Norton.

Smith, Neil. (2001). 'Global social cleansing: Postliberal revanchism and the export of zero tolerance.' Social Justice, 28(3): 68-74.

Smith, Neil. (1996). The New Urban Frontier: Gentrification and the Revanchist City. London: Routledge.

Squires, Peter. (ed.). (2008). ASBO Nation: The Criminalisation of Nuisance, Bristol: Policy Press.

Straw, Jack. (1996). Speech By Shadow Home Secretary, Jack Straw, Speech To The NACRO AGM. Available from: www.prnewswire.co.uk/cgi/news/release?id=19432 [Accessed 4 February 2014]

Treadwell, James. (2008). "Call the (fashion) police': How fashion became criminalised,' Papers from the British Criminology Conference, (8): 117-33.

U2. (1981). October. Island Records. 
von Hirsch, Andrew. and Simester, A. P. (2006). Incivilities: Regulating Offensive Behaviour. Oxford: Hart Publishing.

Walker, Samuel. (1984). "Broken Windows' and fractured history: The use and misuse of history in recent patrol analysis.' Justice Quarterly, 1(1): 75-90.

Ward, Colin. (ed.). (1973). Vandalism. London: The Architectural Press.

Wilson, James Q. and Kelling, George L. (1982) 'Broken windows: The police and neighbourhood safety.' The Atlantic Monthly, 249(3): 29-38.

Young, Alison. (2014). Street Art, Public City: Law, Crime and the Urban Imagination. Abingdon: Routledge.

Zimbardo, Philip G. (1973). 'A field experiment in auto shaping,' in Colin Ward (ed.) Vandalism, London: The Architectural Press.

\section{Legislation}

1723 Black Act

1998 Crime and Disorder Act

2003 Anti-Social Behaviour Act

2014 Anti-Social Behaviour, Crime and Policing Act

\section{Contributor}

Andrew Millie is Professor of Criminology and Director of the Criminology Research Group at Edge Hill University. His current research spans criminology, philosophy and human geography.

\footnotetext{
${ }^{1}$ Chav - thought to derive from the Romany for a small child, or from the Kent town of Chatham meaning 'Chatham girl' or 'Chatham average,' or even as 'Council House and Violent' (see Hayward and Yar, 2006).

${ }^{2} \mathrm{Ned}$ - a Scottish term thought to derive from 'non-educated delinquent' (Brown, 2008).

${ }^{3}$ Anti-Social Behaviour Act 2003 s.30-6
} 